УДК 355.015 (477)

ВИЗДРИК В.С.

https://orcid.org/0000-0001-5427-5825

ТКАЧУК П.О.

https://orcid.org/0000-0002-2601-2742

https://doi.org/10.33577/2313-5603.36.2021.45-60

\title{
РОСІЙСЬКО-ГРУЗИНСЬКА (2008 Р.) ТА ВІРМЕНО- АЗЕРБАЙДЖАНСЬКА (2020 р.) ВІЙНИ В УКРАЇНСЬКОМУ СУСПІЛЬНО-ПОЛІТИЧНОМУ ДИСКУРСІ
}

Аналізуються російсько-грузинська та вірмено-азербайджанська війни у візії української суспільно-політичної думки. Акцентовано увагу на інтерпретації перебігу бойових дій українською політичною елітою, представниками політичних партій, провідними мас-медіа країни. Показано ставлення вищого керівництва держави, центральних органів влади до збройних конфліктів у Кавказькому регіоні, наголошено на їх підтримці територіальної цілісності Грузії та Азербайджану. Відзначено, що події «п'ятиденної війни» у Грузії національнопатріотична українська громадськість розцінювала крізь призму можливого вторгнення російських військ на територію Української держави, зокрема на Кримський півострів. Зазначено, що прихильники Російської Федерації звинувачували керівництво Грузії у спробі дестабілізації етнополітичної ситуації у Кавказькому регіоні, покладали на нього відповідальність за численні жертви та руйнування. Показано, що значний відгомін в українській суспільно-політичній думці отримали події вірмено-азербайджанського збройного протистояння, зважаючи на підтримку Російською Федерацією не визнаних європейськими державами республік Закавказзя, а також її окупацію Кримського півострова.

Ключові слова: російсько-грузинська війна, вірмено-азербайджанська війна, суспільно-політична думка, Україна, засоби масової інформації, політична еліта.

Актуальність проблеми. Воєнні конфлікти у Кавказькому регіоні - одна 3 тематичних ніш, яка більше ніж два десятиліття перебуває у центрі уваги політичної еліти України, експертіваналітиків, відображається на шпальтах періодичних видань. Особливу увагу український соціум звертає на російськогрузинський збройний конфлікт (2008р.), оскільки чимало експертів із цією війною пов'язує агресію РФ 2014 року у

Виздрик Віталій Степанович, доктор історичних наук, професор, професор кафедри гуманітарних наук Національної академії сухопутних військ імені гетьмана Петра Сагайдачного, м. Львів.

Ткачук Павло Олександрович, ад’юнкт науково-організаційного відділу Національної академії сухопутних військ імені гетьмана Петра Сагайдачного, м. Львів.

(С Виздрик В.С., Ткачук П.О., 2021 
Криму. Зазначають, що лідер РФ В. Путін усвідомив свою безкарність, переконався у: а) недієздатності політичних інститутів ЄС; б) «неповороткості» НАТО, яке продемонструвало нездатність оперативно реагувати на виклики сучасності. У контексті українських реалій (окупація Кримського півострова) значне зацікавлення українського політикуму та ЗМІ викликали також події 44-денної вірмено-азербайджанської війни, зважаючи на спробу Азербайджану силою зброї відновити контроль над територією (Нагірний Карабах), яку понад три десятиліття контролювали сепаратисти у співпраці з Вірменією та Росією.

Аналіз історіографії. Сучасна українська історіографія, на жаль, не приділяє належної уваги візії українського суспільства щодо подій у Кавказькому регіоні. Джерельну основу статті становлять матеріали українських 3МI, інформаційні звернення, повідомлення політичних партій, публічні виступи української політичної/соціокультурної еліти, документи центральних органів влади, мемуари відомих громадсько-політичних діячів. Основна мета розвідки - аналіз подій російсько-грузинської та вірменоазербайджанської війн крізь призму української суспільнополітичної думки.

Виклад основного матеріалу. 3 геополітичної точки зору на сьогодні Кавказький регіон - один із найнестабільніших, зважаючи на періодичні спалахи військово-політичних конфліктів. У 2008 р. окреслену тезу підтвердила російсько-грузинська війна, яка сколихнула світову громадськість, знайшла широкий відгомін в українській суспільно-політичній думці. Ї̈і аналіз доречно розпочати із книги третього Президента України В. Ющенка «Недержавні таємниці. Нотатки на берегах пам'яті» (2014р.), який у розділі «Грузія 08.08.08» подав власне бачення тогочасних подій, акцентувавши увагу на бездіяльності українського уряду та підступності опозиції. «По факту агресії з боку Росії ані Парламентом України, ані урядом на чолі з Юлією Тимошенко не була дана відповідна оцінка, - писав Віктор Ющенко. - Я не розраховував на велику підтримку, але мені здавалося, що до цього зобов'язує етика: уряд мав встати на позицію президента i підтримати іï, бо це позиція України. Ось це - по-перше. А подруге, опозиція була ще більш зухвалою, іще більш цинічною це була друга держава у державі. I якщо згадати тодішні новини, 
абсолютна більшість українських каналів копіювали подачу, стилістику і зміст російських новин» (Віктор Ющенко: Чому після Грузї̈- Украӥна, 2021).

Власне В. Ющенко звертає увагу громадськості на тому факті, що «оцінки цього конфлікту на українських каналах надто часто були тотожними тим, які звучали з кремлівських рупорів». Він констатував, що «з боку опозиції продовжувалася необмежена критика дій президента України - і це була новина номер один. Опозиція, взагалі побоялась виступити одним фронтом за українські інтереси, хоча, можливо, в опозиційній Партії регіонів були й такі люди, які вважали, що це небезпека для України також. Але корпоративні розрахунки виявилися сильнішими, ніж національні» (Віктор Ющенко: Чому після Грузї- Україна, 2021).

«Хвалити Ющенка в Україні - річ вкрай невдячна. Та й, будемо чесними, хіба багато є причин для цього? Впевнений, частина скаже, що заслуг у третього президента немає взагалі. А час його президентства - це час розчарувань і втрачених можливостей. Але 7 серпня, як на мене, треба віддати йому належне. Саме цього дня 12 років тому почалась російсько-грузинська війна. I поведінка Ющенка тоді заслуговує на повагу. Не лише через зброю, яку Україна постачала до Грузії..», - писав журналіст «Радіо Свобода» Л. Стек (Треба віддати Ющенку належне..., 2021) .

Власну оцінку російсько-грузинському збройному конфлікту висловив голова Верховної Ради України А. Яценюк. У перший день воєнного конфлікту він провів консультації в режимі телефонних розмов із спікером грузинського парламенту Д. Бакрадзе, головою Ради Федерації Федеральних Зборів Російської Федерації С. Мироновим та спікером Державної Думи Російської Федерації Б. Гризловим. Головною темою обговорення стала ситуація, що склалася в зоні грузино-південноосетинського конфлікт (Голова Верховної Ради України Арсеній Яцеенюк провів консультації..., 2021). А. Яценюк закликав своїх співрозмовників зробити все можливе, аби «негайно припинити бойові дії та розпочати мирні переговори з метою переведення вирішення конфлікту у мирне русло» (Голова Верховної Ради Украӥни Арсеній Яценюк провів консультації..., 2021). 
Висловлюючи свою особисту позицію щодо російськогрузинського збройного конфлікту А. Яценюк зазначав, що «визнання Російською Федерацією незалежності Південної Осетії та Абхазії відбулося всупереч численним резолюціям Ради Безпеки ООН, у тому числі, і № 1582 від 28 січня 2005 року та №1808 від 25 квітня 2008 року, які визнають дотримання позицій всіх держав-членів, у тому числі і Російською Федерацією, принципів суверенітету, незалежності, територіальної цілісності Грузії в межах іiі міжнародно визнаних кордонів...» (Позиція Голови Верховної Ради України А.П. Яценюка..., 2021).

Констатуємо: позиція провладних політичних сил України була на боці Грузії, однак варто визнати той факт, що діаметрально протилежну точку зору відстоювала українська опозиція (КПУ, Партія Регіонів та ін.). «Грузія, почавши вночі війну в Південній Осетії з обстрілу і вбивства мирних жителів, діяла, м'яко кажучи, надто емоційно і злочинно», - відзначав, зокрема, В. Янукович. Лідер української опозиції підкреслив, що Росія «явно не була ініціатором цього конфлікту». Він також заявив, що «будь-які спроби насильно загнати Україну в НАТО приречені на провал» (В. Янукович: Дї Грузії в П.Осетї - злочин..., 2021).

Однак, не усі члени Партії Регіонів дотримувалися подібних переконань. Так, міністерка охорони здоров'я Р. Богатирьова відповідаючи на запитання журналістів про те, чи підтримує вона позицію Президента В. Ющенка щодо територіальної цілісності Грузії чи схиляється на бік В. Януковича, який закликав до визнання Південної Осетії та Абхазії, сказала, що «Янукович висловив лише власну думку, яка не відображає позицію партії». Як результат, 1 вересня 2008 р. Партія Регіонів виключила іiі зі свого складу та зі складу Політради. Водночас один із лідерів регіоналів О. Єфремов, зазначив, що заява В. Януковича була результатом консолідованої точки зору Політради Партії Регіонів. «Це не була думка однієї людини», - резюмував він (Чи розколюеться Партія регіонів через війну в Грузії і НАТО, 2021).

Значно радикальнішим у своїх поглядах були українські комуністи. Так, П. Симоненко узагалі вважав необхідним порушити кримінальну справу за фактом незаконного постачання 
української зброї до Грузії. «Той, хто своїми незаконними діями і за рахунок українського народу сприяв озброєнню режиму Саакашвілі [Президент Грузії - Авт.], повинен відповісти перед законом як міжнародний злочинець» - відзначав він. При цьому лідер комуністів підкреслив, що у нього «немає ніяких сумнівів», що Президент України В. Ющенко був ознайомлений «3 планами свого кума Саакашвілі про розв'язування війни на Кавказі». Він наголошував, що поставки української зброї до Грузії, «з благословення Білого дому», були давно узгоджені «між кумамипрезидентами» і спрямовані на підготовку «варварського нападу» на мирне південно-осетинське місто (Симоненко хочет уголовное дело по поставкам оружия в Грузию, 2021).

Парламент України намагався висловити власну позицію у питанні російсько-грузинської війни. Народні депутати підготували 7 постанов Верховної Ради VI скликання, в яких намагалися виразити свою позицію щодо російсько-грузинського конфлікту, об'єднавши їх під загальною вивіскою «Про військову агресію Росії в Грузії». Жодна 3 цих постанов не отримала достатньої кількості голосів для прийняття (Як Верховна Рада у 2008 роиі [не] визнавала агресію Росії проти Грузї, 2021). Ініціаторами п’яти постанов були депутати 3 коаліції («Наша Україна Народна Самооборона», «Блок Юлії Тимошенко»), ще двох опозиційні депутати. Депутати 3 фракції «НУНС» ініціювали чотири постанови, депутати Партії Регіонів, КПУ та БЮТ - по одній (Постанова Верховної Ради України «Про визнання незалежності Республіки Південна Осетія та Республіки Абхазія», 2021).

«Відмінність цих постанов полягала у тому, що їх автори порізному трактували та оцінювали дії Росії в Грузії» (Постанова Верховної Ради України «Про визнання незалежності Республіки Південна Осетія та Республіки Абхазія», 2021), - зауважували журналісти. Загалом всі постанови можна поділити на три групи. Перша - це ті, які засуджували агресію Росії проти Грузії (№ 3053 авторства депутатів В. Ар’єва та Ю. Стеця, № 3054 депутатів Ю. Костенка та Ярослава Джоджика, № 3082 Б. Тарасюка). До другої групи можна віднести проекти № 3076 та № 3076-2, які були більш поміркованими та прямо не 
засуджували дії Російської Федерації. До третьої групи належать постанови № 3070 та № 3076-1, які називали агресором Грузію, а російські війська - «миротворчим контингентом». Автором першої постанови був лідер КПУ П. Симоненко, другої - депутат від Партії Регіонів О. Лукаш (Як Верховна Рада у 2008 роичі [не] визнавала агресію Росї̈ проти Грузї, 2021).

Вірмено-азербайджанський збройний конфлікт $(2020$ р.) поділив українське суспільство на прихильників Азербайджану (переважно проєвропейськи налаштовані громадяни України) та сторонників Вірменії (здебільшого проросійськи налаштовані жителі нашої держави). «Для України це стало додатковим викликом, адже одну зі сторін конфлікту ми визначили серед наших стратегічних партнерів. Це накладає певні зобов'язання, проте дії Києва виявилися зовсім не партнерськими, - зазначав редактор «Свропейської правди» Ю. Панченко (За крок від великої війни: чим особливий новий конфлікт Вірменії та Азербайджану, 2021).

Журналісти зауважували, що на жаль, конфлікт у Нагірному Карабасі не має простого рішення. Він багато у чому відмінний від ситуації у Криму чи на Донбасі, тож, попри схожі елементи, абсолютної аналогії між ними немає. Та попри це, одного дня Києву все ж доведеться визначатися 3 пріоритетами. У тому числі - приміряючи свою відповідь до того, що ми хочемо чути від наших стратегічних партнерів у разі загострення бойових дій між Україною та РФ» (За крок від великої війни: чим особливий новий конфлікт Вірменії та Азербайджану, 2021).

Позиція української влади у період вірмено-азербайджанського збройного конфлікту була послідовною та виваженою. Її озвучив Президент України В. Зеленський: «Україна та Азербайджан підтримують один одного в питаннях відновлення суверенітету та територіальної цілісності обох держав у межах міжнародно визнаних кордонів» (Зеленський $i$ Алієв обговорили війну на Донбасі та конфлікт у Нагірному Карабасі, 2021). Президент України вважав, що на прикладі конфлікту Азербайджану та Вірменії навколо Нагірного Карабаху українці й західні партнери України мають зрозуміти, що «заморожених конфліктів» немає. «Я хотів би, щоб у цьому питанні наша держава, наші медіа, 
наше суспільство й особливо наші західні партнери звернули на це увагу. Їх просто не існує. I ось вам приклад такого. Чому? Тому що він може бути заморожений на деякий час», - сказав він 2 жовтня 2020 р. (Зеленський $і$ Алієв обговорили війну на Донбасі та конфлікт у Нагірному Карабасі, 2021).

Певний дисонанс у цій злагодженій зовнішньополітичній кампанії України викликали слова народного депутата від партії «Слуга Народу» Л. Марченко, яка 1 жовтня 2020 р. заявила, що Україна «не пройде повз» надання військової допомоги Азербайджану, якщо виникне необхідність (Депутатка «слуги» каже, що Украйна за потреби військово підтримає Азербайджан..., 2021). «Україна готова на різних майданчиках підтримувати Азербайджан. Це і військова підтримка, і гуманітарна всім тим, що треба буде в майбутньому. Це військова ситуація», - заявила Л. Марченко в етері «Україна 24» (Депутатка «слуги» каже, щуо Украйна за потреби військово підтримає Азербайджан..., 2021). У відповідь партія «Слуга народу» зробила офіційну заяву, в якій відзначено: «Повідомляємо, що особисті думки депутатів не є офіційною позицією фракції. I, тим паче, офіційною позицією держави. Народні обранці можуть висловлювати свої міркування та пропозиції з будь-яких питань. Проте рішення про надання допомоги іншим державам може ухвалювати тільки уряд та президент України» (У «Слузі народу» прокоментували заяву Марченко щуодо військової допомоги Азербайджану, 2021).

«Що стосується мого ставлення до надання військової допомоги - це прерогатива верховного головнокомандувача..., констатував В. Зеленський. - Тут у нас зрозуміла і виважена позиція: ми закликаємо до діалогу між Азербайджаном і Вірменією і закликаємо до деескалації цього конфлікту. Що стосується відносин з Азербайджаном, вони в останній рік-два особливі, це правда. Вони серйозні, потужні. Ми підтримуємо суверенітет і територіальну цілісність Азербайджану і вони так само завжди, коли ми говоримо про Крим, говорять, що була незаконна анексія Криму і завжди підтримують нашу цілісність» (Зеленський розповів про чітку позииію по Карабаху і військовій допомозі, 2021).

Проросійські політичні сили в Україні декларували свою підтримку Вірменії. Так, І. Ківа (ОПЗЖ) в етері телеканалу 
«NewsOne» озвучив скандальну заяву, в якій заявив, що «конфлікт у Нагірному Карабасі - це продовження тисячолітньої християнсько-мусульманської війни», та додав, що «як християнин буде підтримувати саме Вірменію». У свою чергу, посольство Азербайджану в Україні обурилося закликом народного депутата. «Подібні «висловлювання» народних обранців України не відповідають духу стратегічного партнерства між нашими країнами і можуть викликати лише крайнє обурення серед широкої громадськості як Азербайджану і Туреччини, так і української і світової громадськості», - зауважили в посольстві Азербайджану в Україні (У Раді пропонують ввести кримінальне покарання для політиків за взаємодію з Кремлем, 2021).

У стінах українського парламенту був підготовлений проєкт Постанови «Про Заяву Верховної Ради України щодо ситуації в Нагірному Карабасі» (автор А. Поляков - голова підкомітету 3 питань дотриманням антикорупційного законодавства у сфері реформування оборонно-промислового комплексу Комітету Верховної Ради України 3 питань антикорупційної політики, член депутатської групи «Партія «За майбутнє») (Проект Постанови про Заяву Верховної Ради України щодо ситуащії в Нагірному Карабасі, 2021). У цьому документі відзначено, що Верховна Рада вважає, що вирішення суперечок військовим шляхом є неприпустимим та таким, що порушує норми міжнародного права. Спроби Азербайджану відстояти власні інтереси військовими методами за активного посередництва Туреччини не забезпечать належного і мирного врегулювання конфлікту... Верховна Рада підтримує заклики міжнародної спільноти щодо необхідності якнайшвидшої стабілізації ситуації за рахунок політико-дипломатичних підходів. Альтернативи мирному переговорному процесу не існує» (Проєкт Постанови про Заяву Верховної Ради України щэодо ситуащії в Нагірному Карабасі, 2021).

Проєкт Постанови не підтримало Міністерство закордонних справ України. «Враховуючи, що позиція України стосовно нагірнокарабахського конфлікту, яка містить заклик до припинення війни і кровопролиття та безумовної поваги територіальної цілісності Азербайджану, була неодноразово озвучена Президентом Володимиром Зеленським та Міністром закордонних справ 
Д. Кулебою, МЗС пропонує утриматися від ухвалення Верховною Радою запропонованого проєкту Заяви Верховної Ради України», - резюмували у відомстві (Пропозициї Міністерства закордонних справ Украӥни, 2021).

Натомість у Заяві МЗС України у зв'язку із завершенням війни в Нагірному Карабасі від 11 листопада 2020 р. йдеться про те, що Україна вітає припинення Азербайджаном і Вірменією бойових дій у районі нагірнокарабаського конфлікту. «Вважаємо, що наступним кроком має стати відновлення стабільності i життєдіяльності регіону, а також продовження міжнародних зусиль для досягнення повного врегулювання нагірнокарабаського конфлікту на основі міжнародного права. Україна незмінно і беззастережно підтримує територіальну цілісність Азербайджанської Республіки в міжнародно-визнаних кордонах. Цей принцип є основоположним для України, що досі потерпає від російської агресії і частина території якої залишається під тимчасовою окупацією Росії», - констатували українські дипломати (Заява МЗС Украӥни у зв'язку із завершенням війни в Нагірному Карабасі, 2021).

Віце-прем'єр-міністр - міністр з питань реінтеграції тимчасово окупованих територій України О. Резніков у квітні 2021 р. відвідав азербайджанське місто Агдам (майже 30 років знаходилося під контролем так званої Нагірно-Карабаської Республіки) і вкотре наголосив: «Ми поважаємо територіальну цілісність Азербайджану. Вважаємо, що ніхто не має права змінювати кордони, які встановлені і визнані на міжнародному рівні. Ми завжди будемо на вашому боці. Вважаємо, що на сьогоднішній день у нас є напрямки для взаємодії і партнерства» (Украйнський віце-прем'єр відвідав повернуте Азербайджаном місто в Нагірному Kарабасі, 2021).

Реакція українських медіа на вірмено-азербайджанську війну різнилася. Так, «Радіо Свобода» зазначало: «Азербайджан досяг результатів у війні в Карабасі передусім тому, що покладався не лише на дипломатичні зусилля... Подобається це чи ні, але ця війна показала помилковість заяв деяких політиків, що у XXI-y столітті не залишається місця для вирішення територіальних суперечок воєнним шляхом...» (Війна в Карабасі: уроки для України та ї̈ армї̈, 2021). 
Військовий експерт М. Самусь зазначав, що у XXI столітті «долю війни вирішують високотехнологічні системи - сучасний зв'язок, системи розвідки, системи визначення цілей, системи ураження..., вірмени у своїх відкритих окопах часто ставали легкою мішенню для безпілотників. I це стосується не тільки дронів» (Війна в Карабасі: уроки для України та ї̈ армї, 2021). За словами військового оглядача О. Арестовича, воєнні дії в Карабасі ускладнювалися гірською місцевістю, скельно-бетонними позиціями, які сторони створювали десятки років (Військовий експерт розкрив деталі конфлікту у Нагірному Карабасі, 2021).

Зі свого боку військовий оглядач Ю. Бутусов наголошував, що Україні важливо засвоїти досвід не лише Азербайджану, а й Вірменії. «Нинішне військово-політичне керівництво України ніякої військової реформи не проводить, армія залишається організованою за давно застарілою радянською моделлю стверджував експерт (Війна в Карабасі: уроки для України та ї̈ армії, 2021).

На геополітичний характер збройного протистояння Вірменії i Азербайджану вказував журналіст, публіцист В. Портников: «Уже в перші дні нової карабаської війни мені доводилося стверджувати, що це - не війна Азербайджану проти Вірменії, це не геополітичне посилення Туреччини і навіть не демонстрація переваги «війни дронів» над старою пострадянською армією. А банальна операція відплати, яку президент Росії Володимир Путін організував не стільки проти Карабаху, скільки проти вірменського народу, який наважився відмовитися від корумпованої проросійської влади в ході чергової революції на пострадянському просторі» (Азербайджан і Вірменія пов'язані кривавою мотузкою. Ї̈ вузол знаходиться в Кремлі, 2021).

У статті Д. Поповича, яку він підготував спеціально для інтернет-порталу «Слово і Діло» зазначено: «стає абсолютно очевидним, що наступ у Нагірному Карабасі Азербайджан веде «3 подачі» Анкари. I це не стільки війна між Вірменією i Азербайджаном, скільки війна між Туреччиною i Росією. А розв'язала іiі саме Туреччина, використовуючи дружній ій Азербайджан в якості тарана. Про це свідчить наростаючий масштаб бойових дій і активна позиція турецької сторони. Очевидно, що 
в цьому випадку бойові дії будуть вестися або до останнього азербайджанського солдата, або до вирішення всіх військових завдань, «нарізаних» Реджепом Ердоганом. Якщо Азербайджан зачистить Нагірний Карабах, то з'являється загроза повторення кривавих Сумгаїтських подій» (Азербайджанський таран і турещьький гамбіт: чому почалася війна в Нагірному Карабасі, 2021).

Фахівець 3 міжнародної політики аналітичного центру «Український інститут майбутнього» І. Куса вважав, що «РФ фактично стала на бік Вірменії, хоча не дозволяє собі однозначних заяв, на кшталт Ердогана, і не може собі це дозволити, оскільки $є$ співголовою групи ОБСЄ. Фактично вона виступає за те, щоб зберегти статус-кво, тобто протистоїть військовій ескалації 3 боку Азербайджану і Туреччини» (Війна не може тривати довго..., 2021). «Головною метою Азербайджану у військовому загостренні в Нагірному Карабасі були переговори на вигідних для нього умовах», - підкреслював директор Центру близькосхідних досліджень І. Семиволос. «Я думаю, це образне твердження від Азербайджану - «йти до кінця», тому що ключове завдання Азербайджану - змусити Вірменію сісти за стіл переговорів і на вигідних для себе умовах укласти мир» (Війна за Нагірний Карабах.,, 2021), - підкреслив він.

Загалом в українському суспільно-політичному дискурсі події вірмено-азербайджанського конфлікту не отримали особливого розголосу. Головними політичними подіями 2020 року в світі жителі України вважали вибори у США (29\%), епідемію COVID-19 і пов'язані $з$ нею протиепідемічні заходи $(27,5 \%)$ i тільки 5\% - війну в Нагірному Карабаху".

Висновки. Військові конфлікти у Кавказькому регіоні 2008 і 2020 років знайшли своє відображення в українській суспільнополітичній думці. Політики, експерти, журналісти давали власні оцінки російсько-грузинському та вірмено-азербайджанському

* Дослідження проведене соціологічною службою Центру Разумкова 34 по 9 грудня 2020 року методом інтерв'ю «обличчям до обличчя» за місцем проживання респондентів. Було опитано 2018 респондентів віком від 18 років у всіх регіонах України, за винятком Криму та окупованих територій Донецької та Луганської областей за вибіркою, що репрезентує доросле населення за основними соціально-демографічними показниками. Теоретична похибка вибірки (без врахування дизайн-ефекту) не перевищує $2,3 \%$ з ймовірністю 0,95 . 
збройним конфліктам. Візія (бачення) цих військових конфліктів різнилася в залежності від політичних, ідеологічних чинників. Вивчення досвіду конфліктів у Кавказькому регіоні є корисним для українського політичного та військового керівництва.

\section{Використані посилання}

Азербайджан $і$ Вірменія пов'язані кривавою мотузкою. Ї̈ вузол знаходиться в Кремлі. URL: https://gazeta.ua/blog/54164/azerbajdzhan-i-virmeniyapovyazani-krivavoyu-motuzkoyu-iyi-vuzol-znahoditsya-v-kremli (Дата звернення: 01.06.2021).

Азербайджанський таран $і$ туреиький гамбіт: чому почалася війна в Нагірному Карабасі. URL: https://www.slovoidilo.ua/2020/10/01/kolonka/denyspopovych/svit/azerbajdzhanskyj-taran-tureczkyj-hambit-chomu-pochalasya-vijnanahirnomu-karabasi (Дата звернення: 05.06.2021).

В. Янукович: Дії Грузії в П. Осетії - злочин. URL: https://www.rbc.ru/politics/05/09/2008/5703cec29a79473dc8148bc4 (Дата звернення: 01.04.2021).

Пропозиції Міністерства закордонних справ України до проєкту Закону Украӥни Постанова Верховної Ради Украӥни «Про заяву Верховної Ради Украӥни щодо ситуаиії в Нагірному Карабасі». URL: https://www.kmu.gov.ua/bills/proekt-postanovi-pro-zayavu-verkhovnoi-radi-ukraini-shchodo-situatsii-vnagirnomu-karabasi (Дата звернення: 03.06.2021).

Війна в Карабасі: уроки для України та ї армії. URL: https://www.radiosvoboda.org/a/viyna-v-karabasi-uroky-dlya-ukrainy-ta-yiyi-armiyi/ 30939727.html (Дата звернення: 13.06.2021).

Війна за Нагірний Карабах: експерт назвав головну мету Баку. URL: https://glavred.info/ua/world/voyna-za-nagornyy-karabah-ekspert-nazval-glavnuyu-celbaku-10208645.html (Дата звернення: 12.06.2021).

Війна не може тривати довго. Експерт розповів, за яких умов почнуться переговори щодо Карабаху. URL: https://suspilne.media/68567-ne-moze-trivatidovgo-ekspert-rozpoviv-za-akih-umov-pocnutsa-peregovori-sodo-nagirnogo-karabahu/ (Дата звернення: 01.06.2021).

Військовий експерт розкрив деталі конфлікту у Нагірному Карабасі. URL: https://wz.lviv.ua/news/421184-viiskovyi-ekspert-rozkryv-detali-konfliktu-u-nahirnomukarabasi (Дата звернення: 15.06.2021).

Віктор Ющенко: Чому після Грузії - Україна? URL: https://www.istpravda.com.ua/ columns/2016/08/8/149175/ (Дата звернення: 21.06.2021).

Голова Верховної Ради України Арсеній Яиенюк провів консультащії із Спікером Грузинського парламенту Д. Бакрадзе, Головою Ради Федераиії Федеральних Зборів Російської Федераиії С. Мироновим та Спікером Державної Думи Російської Федерації Б. Гризловим щодо мирного врегулювання ситуаиії в зоні грузино-південноосетинського конфлікту. URL: https://www.rada.gov.ua/ news/Povidomlennya/15549.html?search=\%D0\%9E\%D1\%81\%D0\%B5\%D1\%82\% D1\%96\%D1\%97 (Дата звернення: 01.06.2021).

Депутатка «слуги» каже, що Україна за потреби військово підтримає Азербайджан. Аваков пропонує шукати ій таблетки. URL: https://hromadske.ua/ 
posts/deputatka-marchenko-zayavila-sho-ukrayina-za-potrebi-vijskovo-pidtrimayeazerbajdzhan-avakov-zaperechuye (Дата звернення: 11.06.2021).

За крок від великої війни: чим особливий новий конфлікт Вірменії та Азербайджану. URL: https://www.eurointegration.com.ua/articles/2020/09/28/7114757/ (Дата звернення: 07.06.2021).

Заява МЗС Украӥни у зв'язку із завершенням війни в Нагірному Карабасі. URL: https://mfa.gov.ua/news/zayava-mzs-ukrayini-u-zvyazku-iz-zavershennyam-vijniv-nagirnomu-karabasi (Дата звернення: 01.06.2021).

Зеленський і Алієв обговорили війну на Донбасі та конфлікт у Нагірному Карабасі. URL: https://www.ukrinform.ua/rubric-polytics/2839561-zelenskij-i-alievobgovorili-vijnu-na-donbasi-ta-konflikt-u-nagirnomu-karabasi.html (Дата звернення: 13.06.2021).

Зеленський розповів про чітку позицію по Карабаху $і$ військовій допомозі. URL: https://www.pravda.com.ua/news/2020/10/2/7268605/ (Дата звернення: 05.06.2021).

Позииія Голови Верховної Ради України А.П. Яиенюка стосовно визнання Російською Федерацією незалежності Південної Осетії $і$ Абхазї. URL: https://www.rada.gov.ua/news/Novyny/15428.html?search=\%D0\%9E\%D1\%81\%D 0\%B5\%D1\%82\%D1\%96\%D1\%97 (Дата звернення: 02.06.2021).

После войны в Грузии сторонники Симоненко и Януковича стали любить Россию еще больше. URL: https:/glavnoe.ua/news/n12742 (Дата звернення: 17.06.2021).

Постанова Верховної Ради Украӥни «Про визнання незалежності Республіки Південна Осетія та Республіки Абхазія». URL: https://ips.ligazakon.net/document/DF2DN00A?an=3 (Дата звернення: 03.06.2021).

Проєкт Постанови про Заяву Верховної Ради України щзодо ситуації в Нагірному Карабасі. URL: http://w1.c1.rada.gov.ua/pls/zweb2/webproc4_1?pf3511=70248 (Дата звернення: 15.06.2021).

Симоненко хочет уголовное дело по поставкам оружия в Грузию. URL: https://www.pravda.com.ua/rus/news/2008/08/9/4446892/ (Дата звернення: 22.06.2021).

Треба віддати Ющченку належне: 12 років тому російські бомбардувальники в Грузї̈ збивалися украӥнськими ракетами. URL: https://novynarnia.com/2020/08/07/yuschenko-georgia/ (Дата звернення: 04.06.2021).

У «Слузі народу» прокоментували заяву Марченко щзодо військової допомоги Азербайджану. URL: https://www.unian.ua/politics/azerbaydzhan-u-sluzinarodu-prokomentuvali-zayavu-marchenko-shchodo-viyskovoji-dopomogi-azerbaydzhanunovini-ukrajina-11168402.html (Дата звернення: 01.06.2021).

У Раді пропонують ввести кримінальне покарання для політиків за взаємодію 3 Кремлем. URL: http:///UMOLODA.KYIV.UA/NUMBER/3647/2006/150788/ (Дата звернення: 13.06.2021).

Український віце-прем'єр відвідав повернуте Азербайджсаном місто в Нагірному Карабасі. URL: https://lb.ua/news/2021/04/14/482379_ukrainskiy_vitsepremier_ vidvidav.html (Дата звернення: 11.06.2021).

Чи розколюється Партія регіонів через війну в Грузї $і$ HАTO? URL: https://www.pravda.com.ua/articles/2008/09/8/3550222/ (Дата звернення: 14.06.2021). 
Як Верховна Рада у 2008 роиі [не] визнавала агресію Росї проти Грузії. URL: https://rada.oporaua.org/novyny/novini/23287-yak-verkhovna-rada-u-2008-rotsine-vyznavala-ahresiiu-rosii-proty-hruzii (Дата звернення: 12.06.2021).

\section{References}

Azerbaijan and Armenia are connected by a bloody rope. Its hub is in the Kreml. URL: https://gazeta.ua/blog/54164/azerbajdzhan-i-virmeniya-povyazanikrivavoyu-motuzkoyu-iyi-vuzol-znahoditsya-v-kremli [ukr]

Azerbaijani ram and Turkish gambit: why the war in Nagorno-Karabakh began. URL: https://www.slovoidilo.ua/2020/10/01/kolonka/denys-popovych/svit/azerbajdzhanskyj-taran-tureczkyj-hambit-chomu-pochalasya-vijna-nahirnomu-karabasi [ukr]

Viktor Yanukovych: Georgia's actions in Ossetia are a crime. URL: https://www.rbc.ru/politics/05/09/2008/5703cec29a79473dc8148bc4 [ukr]

Proposals of the Ministry of Foreign Affairs of Ukraine to the Draft Law of Ukraine of the Verkhovna Rada of Ukraine "On the Statement of the Verkhovna Rada of Ukraine on the Situation in Nagorno-Karabakh". URL: https://www.kmu.gov.ua/bills/proekt-postanovi-pro-zayavu-verkhovnoi-radiukraini-shchodo-situatsii-v-nagirnomu-karabasi [ukr]

The war in Karabakh: lessons for Ukraine and its army. URL: https://www.radiosvoboda.org/a/viyna-v-karabasi-uroky-dlya-ukrainy-ta-yiyiarmiyi/30939727.html [ukr]

Nagorno-Karabakh war: expert named Baku's main target. URL: https://glavred.info/ua/world/voyna-za-nagornyy-karabah-ekspert-nazval-glavnuyucel-baku-10208645.html [ukr]

The war cannot last long. The expert told under what conditions the talks on Karabakh will start. URL: https://suspilne.media/68567-ne-moze-trivati-dovgo-ekspertrozpoviv-za-akih-umov-pocnutsa-peregovori-sodo-nagirnogo-karabahu/ [ukr]

A military expert has revealed details of the Nagorno-Karabakh conflict. URL: https://wz.lviv.ua/news/421184-viiskovyi-ekspert-rozkryv-detali-konfliktu-u-nahirnomukarabasi [ukr]

Victor Yushchenko: Why Ukraine after Georgia? URL: https://www.istpravda.com.ua/columns/2016/08/8/149175/ [ukr]

The Chairman of The Verkhovna Rada of Ukraine, Arseniy Yatsenyuk, consulted with the Speaker of the Georgian Parliament D. Bakradze, the Chairman of the Federation Council of the Federal Assembly of the Russian Federation S. Mironov and the Speaker of the State Duma of the Russian Federation B. Gryzlov on the peaceful settlement of the Georgian-South Ossetian conflict. URL: https://www.rada.gov.ua/news/Povidomlennya/15549.html?search=\%D0\%9E\%D1\%81\%D0\%B5\%D1\%82\% D1\%96\%D1\%97 [ukr]

The "servant" deputy says that Ukraine will support Azerbaijan militarily if necessary. Avakov offers to look for her pills. URL: https://hromadske.ua/posts/deputatkamarchenko-zayavila-sho-ukrayina-za-potrebi-vijskovo-pidtrimaye-azerbajdzhan-avakovzaperechuye [ukr] 
One step away from the great war: what is special about the new conflict between Armenia and Azerbaijan. URL: https://www.eurointegration.com.ua/articles/2020/09/28/7114757/ [ukr]

Statement of the Ministry of Foreign Affairs of Ukraine in connection with the end of the war in Nagorno-Karabakh. URL: https://mfa.gov.ua/news/zayava-mzsukrayini-u-zvyazku-iz-zavershennyam-vijni-v-nagirnomu-karabasi [ukr]

Zelensky and Aliyev discuss war in Donbass and conflict in Nagorno-Karabakh. URL: https://www.ukrinform.ua/rubric-polytics/2839561-zelenskij-i-aliev-obgovorilivijnu-na- donbasi-ta-konflikt-u-nagirnomu-karabasi.html [ukr]

Zelensky spoke about a clear position on Karabakh and military aid. URL: https://www.pravda.com.ua/news/2020/10/2/7268605/ [ukr]

Position of the Chairman of The Verkhovna Rada of Ukraine AP Yatsenyuk on the recognition by the Russian Federation of the independence of South Ossetia and Abkhazia. URL: https://www.rada.gov.ua/news/Novyny/15428.html?search=\%D0\%9E\%D1\%81\%D0\%B5\%D1\%82\%D1\%96\%D1\%97 [ukr]

After the war in Georgia, supporters of Symonenko and Yanukovych began to love Russia even more. URL: https://glavnoe.ua/news/n12742 [ukr]

Resolution of the Verkhovna Rada of Ukraine "On Recognition of the Independence of the Republic of South Ossetia and the Republic of Abkhazia". URL: https://ips.ligazakon.net/document/DF2DN00A?an=3 [ukr]

Draft Resolution on the Statement of the Verkhovna Rada of Ukraine on the Situation in Nagorno-Karabakh. URL: http://w1.c1.rada.gov.ua/pls/zweb2/webproc4_1?pf3511=70248

Symonenko wants a criminal case on the supply of weapons to Georgia. URL: https://www.pravda.com.ua/rus/news/2008/08/9/4446892/ [ukr]

We have hand it to Yushchenko: 12 years ago, Russian bombers in Georgia were shot down by Ukrainian missiles. URL: https://novynarnia.com/2020/08/07/yuschenko-georgia/ [ukr]

The People's Service commented on Marchenko's statement on military aid to Azerbaijan. URL: https://www.unian.ua/politics/azerbaydzhan-u-sluzinarodu-prokomentuvali-zayavu-marchenko-shchodo-viyskovoji-dopomogiazerbaydzhanu-novini-ukrajina-11168402.html [ukr]

The Rada proposes to introduce criminal penalties for politicians for interacting with the Kremlin. URL: http:///UMOLODA.KYIV.UA/NUMBER/3647/2006/150788/ [ukr]

The Ukrainian Deputy Prime Minister visited the city returned by Azerbaijan in Nagorno-Karabakh. URL: https://lb.ua/news/2021/04/14/482379_ukrainskiy_vitsepremier_vidvidav.html [ukr]

Is the Party of Regions split over the war in Georgia and NATO? URL: https://www.pravda.com.ua/articles/2008/09/8/3550222/ [ukr]

As the Verkhovna Rada in 2008 [did not] recognize Russia's aggression against Georgia. URL: https://rada.oporaua.org/novyny/novini/23287-yak-verkhovna-radau-2008-rotsi- ne-vyznavala-ahresiiu-rosii-proty-hruzii [ukr] 


\section{Vyzdryk V., Tkachuk P. \\ RUSSIAN-GEORGIAN (2008) AND ARMENIAN-AZERBAIJAN (2020) WARS IN THE UKRAINIAN SOCIO-POLITICAL DISCOURSE}

The Russian-Georgian and Armenian-Azerbaijani armed conflicts are characterized in the vision of Ukrainian socio-political thought. Emphasis is placed on the interpretation of the course of hostilities by the Ukrainian political elite, representatives of political parties, and the country's leading mass media. The attitude of the top leadership of the state and central authorities to the armed conflicts in the Caucasus region is shown, and their support for the territorial integrity of Georgia and Azerbaijan is emphasized. It is proved that Ukrainian socio-political thought reacted briskly to the course of the armed confrontation between the Russian-Georgian Armed Forces (2008) and the armies of Azerbaijan and Armenia (2020). It was stated that the Ukrainian mass media (media) covered in detail the Karabakh conflict, the occupation of part of the territory of Georgia by Russian troops, and provided their own interpretation of the causes and consequences of the armed escalation in the region of hostilities. It is noted that the events of the "five-day war" in Georgia were viewed by the national-patriotic Ukrainian public through the prism of a possible invasion of Russian troops into the territory of the Ukrainian state, in particular the Crimean peninsula. It is noted that sympathizers of the Russian Federation accused the Georgian leadership of trying to destabilize the ethno-political situation in the Caucasus region, blaming it for numerous casualties and destruction. It is shown that the events of the Armenian-Azerbaijani armed confrontation received a significant echo in Ukrainian socio-political thought, given the Russian Federation's support for the republics not recognized by European states in the Caucasus, as well as its occupation of the Crimean Peninsula (2014).

Keywords: Russian-Georgian war, Armenian-Azerbaijani war, socio-political thought, Ukraine, mass media, political elite. 